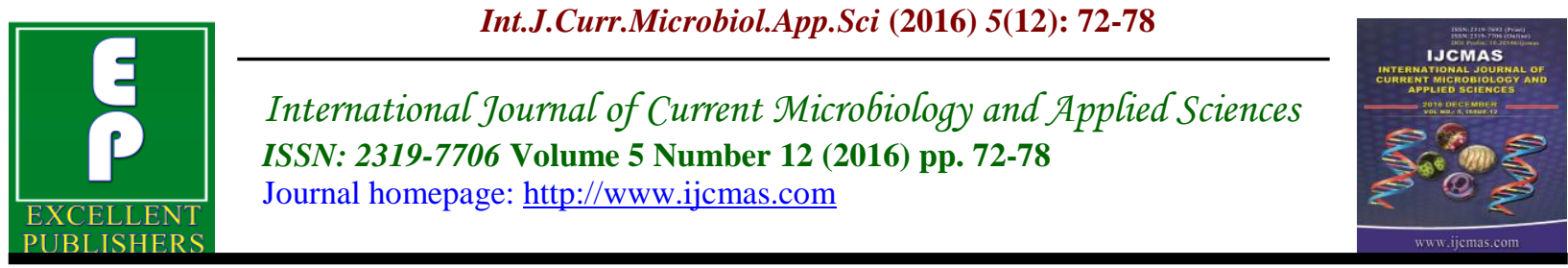

Original Research Article

http://dx.doi.org/10.20546/ijcmas.2016.512.008

\title{
Comparison of Phytochemical and invitro Antimicrobial Evaluation of Methanolic Extracts of Garcinia gummi-gutta
}

\author{
M. Jayasudha ${ }^{1 *}$, R.K. Sumathi ${ }^{1}$ and M.D. Dinesh ${ }^{2}$ \\ ${ }^{1}$ Department of Microbiology, Sri Ramakrishna College, for Women, Coimbatore, India \\ ${ }^{2}$ Department of Microbiology, Pazhassiraja College, Pulpally, India
}

*Corresponding author:

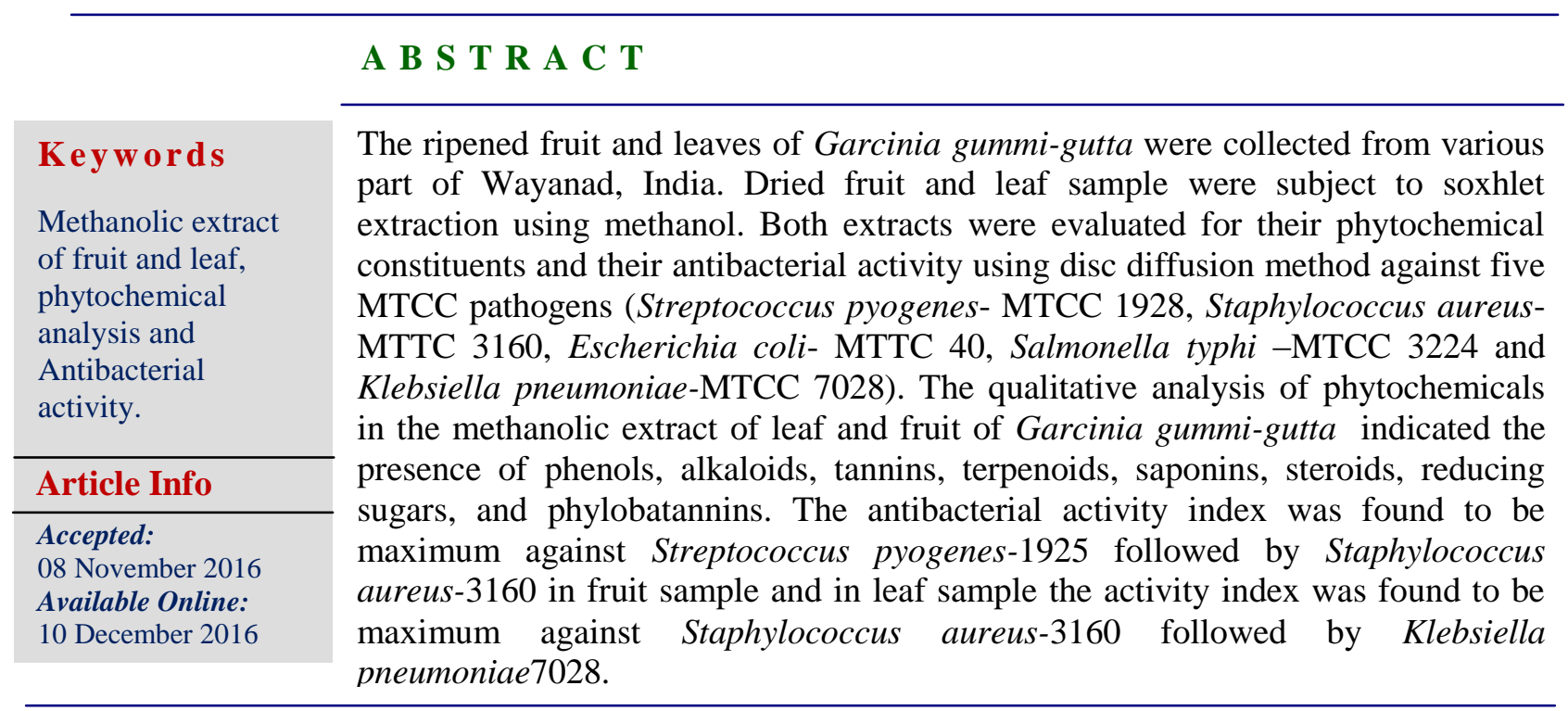

\section{Introduction}

World Health Organisation (WHO) has defined medicinal plants as plants that contain properties or compounds that can be used for therapeutic purposes or those that synthesize metabolites to produce useful drugs. The plant Garcinia gummi-gutta $\{\mathrm{L}\}$ Robson (G.cambogia, G.quaesita) belongs to the family Guttiferae (Clusiaceae). The plants are shrubs or trees with yellow or greenish juice. This fruit is also called Malabar Tarmarind. The fruit rind of the plant is commonly used in various food preparations in southern India especially, mainly in Kerala. The fruits of the plant are commercially important for its valuable chemical components like hydroxyl citric acid, tarteric acid, camogin, euxanthone, gucinol, reducing sugars and fats. Dmitrity obolskiy et al., (2009) observed that the plant is commercially important as their fruit extracts are used for various treatments such as astringent, demulcent, rheumatism, bowel complaints and purgative. Karnataka forest publication 2011 has reported these plants as forest trees with medicinal aspects. Hence breeding of these trees has to be boosted. 
Carlos et al., (2008) suggested that the main component of the fruits is hydroxyl citric acid and is used in anti obesity drugs.

\section{Materials and Methods}

\section{Collection of samples}

The ripened fruit and leaves of Garcinia gummi-gutta were collected from various parts of Wayanad, India. Approximately 1 $\mathrm{kg}$ of fruit and leaf samples was collected in polythene bags and taken to the laboratory. The samples are washed with clean sterile water and shade dried. After drying the samples are pulverized using a mechanical blender into coarse powder and then transferred into air tight container.

\section{Extraction Process}

Approximately $20 \mathrm{~g}$ of dried samples were weighed and was soxhleted using methanol as the solvent. The crude extract thus collected was completely evaporated and stored at $4^{\circ} \mathrm{C}$ until further use.

\section{Preliminary phytochemical screening}

Both extracts were subjected to various qualitative chemical tests for detecting the presence of phyto-constituents like alkaloids, flavanoids, tannins, saponins, phenolic compounds, reducing sugar, terpenoids, carotenoid, gum and phylobatannins. Screening of the extract for various phytochemical constituents was carried out using standard methods of Raaman, 2006 and Sofowora, 1993.

\section{Detection of alkaloids}

\section{Mayer s Test}

To a few $\mathrm{ml}$ of the extracts, one or two drops of Mayer s reagent [Mercuric chloride $(1.36 \mathrm{~g})$ was dissolved in $60 \mathrm{ml}$ of water and potassium iodide $(5.0 \mathrm{~g})$ was dissolved in $10 \mathrm{ml}$ of water. The two solutions were mixed and made up to $100 \mathrm{ml}$ with water] was added by the side of the test tube. A white creamy precipitate indicated a positive result.

\section{Wagner s Test}

To a few $\mathrm{ml}$ of the extracts, few drops of Wagner $\mathrm{s}$ reagent [Iodine $(1.27 \mathrm{~g})$ and potassium iodide $(2 \mathrm{~g})$ was dissolved in $5 \mathrm{ml}$ of water and made up to $100 \mathrm{ml}$ with distilled water] was added by the side of the test tube. A reddish brown precipitate indicates a positive result.

\section{Detection of phenolic compounds and tannins}

a) Ferric chloride Test

To the extracts, few drops of neutral $5 \%$ ferric chloride solution were added. A dark green colour indicated the presence of phenolic compounds.

b) Lead Acetate Test

To the extracts, $3 \mathrm{ml}$ of $10 \%$ lead acetate solution was added. A bulky white precipitate indicated the presence of phenolic compounds.

\section{Detection of presence of saponins}

The extracts was diluted with $20 \mathrm{ml}$ of distilled water and shaken well or mixed well with cyclomixer; formation of froth which is stable for 15 minutes indicated presence of saponins.

\section{Detection of carbohydrate}

a) Fehling's test

To $2 \mathrm{ml}$ of aqueous solution of extract 5-8 drops of Fehling $\mathrm{s}$ solution was added. It 
was kept in the boiling water bath for few minutes, formation of brick red precipitate indicated presence of reducing sugar.

b) Benedict's test

To $1 \mathrm{ml}$ of aqueous extract $1 \mathrm{ml}$ of Benedict's reagent was added and kept in a boiling water bath for 2 minutes, formation of red precipitate indicated presence of reducing sugar.

\section{Detection of Triterpenoids and steroids}

a) Salkowski test

The extract was treated with few drops of con. Sulfuric acid, shaken well and allowed to stand for some time, red color at the lower layer indicated the presence of steroids and formation of yellow colored lower layer indicated the presence of triterpenoids.

\section{Detection of phylobatannins}

$10 \mathrm{ml}$ of aqueous extract were boiled with $1 \% \mathrm{HCl}$ taken in a test tube. Deposition of a red color indicated the presence of phylobatannins.

\section{Antimicrobial activity- Disc diffusion method (Acar et al., 1991; Doughari, 2006)}

The antimicrobial activity was evaluated by disc diffusion method. The stock solution of the extract was prepared in the concentration of $0.1 \mathrm{~g} / \mathrm{ml}$. From that various volume of 15 $\mu 1,20 \mu 1,25 \mu 1,30 \mu 1,35 \mu 1$ and $40 \mu 1$ corresponding to $1.5 \mathrm{mg} / \mathrm{ml}, 2 \mathrm{mg} / \mathrm{ml}, 2.5$ $\mathrm{mg} / \mathrm{ml}, 3 \mathrm{mg} / \mathrm{ml}, 3.5 \mathrm{mg} / \mathrm{ml}$ and $4 \mathrm{mg} / \mathrm{ml}$ were taken separately. For the determination of antimicrobial activity, bacterial cultures were adjusted to 0.5 McFarland turbidity standard and lawn cultured into Muller-Hinton agar plates $(\mathrm{g} / \mathrm{l})$ (Beef extract-300, Casein acid hydrolysate-
17.50, Starch-1.50, Agar-17.00, pH-7.3).The cultures used were Streptococcus pyogenesMTCC 1928, Staphylococcus aureus-MTTC 3160,Escherichia coli- MTTC 40,Salmonella typhmurium -MTCC 3224 and Klebsiella pneumoniae-MTCC 7028. Sterile filter paper discs impregnated with extracts of different concentration were applied over each of the culture plates seeded with the $0.5 \mathrm{McF}$ arland cultures of bacteria (distilled water served as negative control and chloramphenicol as positive control). Bacterial cultures were then incubated at $37^{\circ} \mathrm{C}$ for 24 hours. Antibacterial activity was determined by measuring the zone of inhibition around each paper disc. The experiment was done in triplicates.

\section{Result and Discussion}

\section{Preliminary phytochemical screening of Garcinia gummi-gutta}

The qualitative analysis of phytochemicals in the methanolic extract of leaf and fruit of Garcinia gummi-gutta indicated the presence of phenols, alkaloids, tannins, terpenoids, saponins, steroids, reducing sugars, and phylobatannins. The results are tabulated in table -1 .

Phytochemical analysis conducted on the fruit and leaf extract disclosed medicinal as well as physiological activities (Tarali chowdhury, 2014).

Phenols are found in the natural world, especially in the plant kingdom. Some phenols are proved to have hypertensive effects and antioxidant properties. Phenolic compounds are one of the largest and most ubiquitous groups of plant metabolites (Singh et al., 2007).

Saponins present in plants have been suggested as possible anti- carcinogens. 
However, the anticarcinogenic effects of saponins from commonly consumed plant foods have not been studied (Rao et al., 2010). Terpenoids have medicinal value such as anti-carcinogenic, antimalarial, antimicrobial and diuretics activity (Deganhardt, 2003 and Pichersky and Gershezon, 2002). Phylobatannins and steroids which were found to be present in all the extract of the plant parts and they are of tremendous importance and interest in pharmaceutical research (Rao et al., 2003).

Alkaloids are used medicinally. They provide information to determine lead structures of novel synthetic drugs. These compounds have antimicrobial activity by inhibiting DNA topoisomerase (Bonjean K., 1998).Tannins which helps to reduce the risk of coronary heart diseases (Janaky Ranjithkumar, 2010).

\section{Antibacterial Activity of Garcinia gummi- gutta}

The antibacterial effect was determined using the disk diffusion method as outlined in (Bauer et al., 1966). The zones of bacterial inhibition were measured to the nearest whole millimeter $(\mathrm{mm})$. Diameter of zone of inhibition $>10 \mathrm{~mm}$ were considered active (Dosumu et al., 2006). The antibacterial activity found in the plant extracts have been attributed to some of the secondary metabolites (Cowman, 1999).

\section{Antibacterial activity of fruit extract of Garcinia gummi-gutta}

The methanolic extract of $G$ gummi-gutta showed good to moderate antibacterial effect on all the strains that was tested. Various extract showed different effects on the bacteria, which were summarized in Table 2 and plate1-5. For this study two gram positive bacteria (Streptococcus pyogenes-1925, S. aureus-3160) and three gram negative bacteria (E. coli-40, $K$. pneumonia-7028, S.typhi-3224) were used. Chloramphenicol (30 mcg) was used as a positive control. The main reason to use Chloramphenicol was because of its broadspectrum antibiotic activity and it was seen that various multi drug resistant bacteria were still sensitive to Chloramphenicol (Fernández et al., 2012). From the 'Standard Zone Size Interpretative Chart for Chloramphenicol', the results were interpreted. For Streptococcus pyogenes1925, the methanolic extract showed an inhibition zone of about $28 \mathrm{~mm}$, which indicates that the methanolic extract had shown a good antibacterial activity and $S$. aureus showed a maximam inhibition zone of about $24 \mathrm{~mm}$. The antimicrobial activity index of methanolic extract of fruit extract of Garcinia gummi-gutta was found to be maximum against Streptococcus pyogenes1925 followed by Staphylococcus aureus3160. The extract shows moderate level of activity against rest of the organisms.

\section{Antibacterial Activity of leaf extract of Garcinia gummi-gutta}

In the present investigation, methanolic extract of leaf of Garcinia gummi-gutta were used to assess the antibacterial activity of the plant. It was observed that the methanolic extract of leaf showed $24 \mathrm{~mm}$ zone of inhibition against $S$. aureus-3160and showed $23 \mathrm{~mm}$ zone of inhibition against klebsiella pneumonia-7028. (Maridass et al., 2010) has reported the antibacterial activity of Garcinia gummi-gutta leaf against the growth of Salmonella typhi producing $17 \mathrm{~mm}$ growth inhibition zone. Results obtained in the present study revealed that Garcinia gummi-gutta leaves exhibited growth of Salmonella typhi-3224 producing $21 \mathrm{~mm}$ growth inhibition zone and least inhibition zone of $10 \mathrm{~mm}$ against E.coli-40. 
Table.1 Phytochemical analysis of Garcinia gummi-gutta

\begin{tabular}{|c|c|c|}
\hline Phytochemical tests & Fruit & Leaf \\
\hline Phenols & + & + \\
\hline Alkaloids & - & + \\
\hline Tannins & - & + \\
\hline Saponins & + & - \\
\hline Terpenoids & + & + \\
\hline Steroids & + & + \\
\hline Reducing sugar & + & - \\
\hline Phylobatannins & + & + \\
\hline
\end{tabular}

Table.2 Antibacterial activity of fruit extract

\begin{tabular}{|c|c|c|c|c|c|c|c|}
\hline Test microorganism & \multicolumn{6}{|c|}{$\begin{array}{c}\text { Inhibition zone of fruit extract in mm } \\
\text { Concentration (mg/ml) }\end{array}$} & $\begin{array}{c}\text { Inhibition zone of } \\
\text { Chloramphenicol (2.5 mg/ml) } \\
\text { in mm }\end{array}$ \\
\cline { 2 - 7 } & 4 & 3.5 & 3.0 & 2.5 & 2.0 & 1.5 & 25 \\
\hline $\begin{array}{c}\text { Streptococcus } \\
\text { pyogenes(MTCC } \\
\text { 1925) }\end{array}$ & 28 & 23 & 18 & 15 & 10 & - & 30 \\
\hline $\begin{array}{c}\text { Staphylococcus } \\
\text { aureus( MTCC 3160) }\end{array}$ & 24 & 20 & 18 & 15 & 10 & - & 30 \\
\hline $\begin{array}{c}\text { Escherichia coli } \\
\text { (MTCC 40) }\end{array}$ & 20 & 17 & 14 & 10 & - & - & 20 \\
\hline $\begin{array}{c}\text { Klebsiella pneumonia } \\
\text { (MTCC 7028) }\end{array}$ & 18 & 16 & 14 & 11 & - & - & 33 \\
\hline $\begin{array}{c}\text { Salmonella typhi } \\
\text { (MTCC 3224) }\end{array}$ & 18 & 15 & 13 & 10 & - & - & \\
\hline
\end{tabular}

Table.3 Antibacterial activity of leaf extract

\begin{tabular}{|c|c|c|c|c|c|}
\hline \multirow[t]{2}{*}{ Test microorganism } & \multicolumn{4}{|c|}{$\begin{array}{l}\text { Inhibition zone of leaf extract in } \mathrm{mm} \\
\text { Concentration }(\mathrm{mg} / \mathrm{ml})\end{array}$} & \multirow[t]{2}{*}{$\begin{array}{l}\text { Inhibition zone of Chloramphenicol } \\
(2.5 \mathrm{mg} / \mathrm{ml}) \text { in } \mathrm{mm}\end{array}$} \\
\hline & 2.0 & 3.0 & 4.0 & 5.0 & \\
\hline $\begin{array}{c}\text { Streptococcus } \\
\text { pyogenes (MTCC } \\
1925)\end{array}$ & - & 5 & 12 & 17 & 25 \\
\hline $\begin{array}{c}\text { Staphylococcus } \\
\text { aureus } \\
\text { (MTCC } 3160) \\
\end{array}$ & 6 & 12 & 20 & 24 & 30 \\
\hline $\begin{array}{l}\text { Escherichia coli } \\
(\text { (MTCC 40) }\end{array}$ & - & - & 5 & 10 & 30 \\
\hline $\begin{array}{l}\text { Klebsiella pneumonia } \\
\text { (MTCC 7028) }\end{array}$ & 9 & 14 & 19 & 23 & 20 \\
\hline $\begin{array}{l}\text { Salmonella typhi } \\
\text { (MTCC 3224) }\end{array}$ & 12 & 16 & 19 & 21 & 33 \\
\hline
\end{tabular}

The results of methanolic leaf extract of Garcinia gummi-gutta are tabulated in
Table-3. The activity index was found to be maximum against Staphylococcus aureus- 
3160 followed by Klebsiella pneumoniae7028. The extract shows moderate level of activity against rest of the organisms.

In conclusion, the results acquired from this study concluded that methanolic extract of fruit shows maximum activity than leaf extract. Thus suggest that the identified phytochemical compounds may be the bioactive constituents. Thus Garcinia gummi-gutta is proving to be a valuable reservoir of bioactive compounds of substantial medicinal merit .The observed inhibitory effect of methanolic extract of $G$. gummi-gutta consist of high phenolic compounds in both extractsare an indication of the plant effectiveness in being used as anti - bacterial agent, as it is used in disinfections. The high Saponins content in fruit extract explains its high antibacterial effects. From the above studies we can conclude that G. gummi-gutta showed a good antibacterial activity on all the organisms tested.

\section{Acknowledgement}

The authors of this paper are very much thankful to the Department of Microbiology, Sri Ramakrishna College for women, Coimbatore, Tamil nadu and Pazhassiraja College, pulpally, Wayanad, Kerala.

\section{References}

Acar, J.F. and F.W. Goldstein. 1991. disk susceptibility test. In: antibiotic in laboratory medicine. Loran (Ed), $3^{\text {rd }}$ Edn.

Bauer, A.W., Kirby, W.M.M., Sherris, J.C., Truck, M. 1966. Antibiotic susceptibility testing by a standardized single disc method. American J. Clin. Pathol., 45: 493-496.
Bonjean, K., De Pauw-Gillet, M.C. 1998. J. Ethnopharmocol., vol 69, 1998, 241246.

Carlos, A.R., Rossetto, S., Halmenschlayer, G., Linden, R., Heckler, E., Maria, S., Fernandez, P., Jose, L. Lancho, L. 2008. Evaluation of pharmotherapeutic efficacy of Garciniacambogia plus Amorphophalluskonjac for the treatment of obesity. Phytotheraphy Res., 22(9), 1135-1140.

Cowan, Marjorie Murphy. 1999. "Plant products as antimicrobial agents." Clinical Microbiol. Reviews, 12(4): 564-582.

Deganhardt, J. 2003. Attracting friends to feast on foes: Engineering terpene emission to make crop plant more attractive to herbivore enemies. Curr. Opin. Biotechnol., 14:169-176.

Dmitriy Obolskiy, Ivo Pischel, Nisarat Siriwatanametanon, Michael Heinrich. 2009. Phytotherapy res., Vol 23, Issue 8: $1047-1065$.

Dosumu, O.O., Nwosu, F.O., Nwogu, C.J. 2006. Phytochemical screening and anti-microbial studies of extracts of Hyphaenethebaicalinn (Mart) palmae. Int. J. Trop. Med., 1(4): 186-189.

Doughri, J.H. 2006. antimicrobial activity of jamariindusindica Linn. Trop. J. Parm. Res., 5: 597-603.

Fernández, M., Conde, S., de la Torre, J., Molina-Santiago, C., Ramos, J.L., et al. 2012. Mechanisms of resistance to chloramphenicol in Pseudomonas putida KT2440. Antimicrob. Agents Chemother., 56: 1001-1009.

Janaky Ranjithkumar. 2010. J. Chem. Pharm. Res., 2(4): 371-377.

Maridass, M., Ramesh, U. and Raju, G. 2010. Evaluation of phytochemical, Pharmacognostical and Antibacterial Activity of Garcinia gummi-gutta Leaves. Pharmacologyline, 1: 832837. 243. 
Pichersky, E. and Gershezon, J. 2002. The formation and function of plant volatiles, perfumes for pollinator attraction and defence. Curr. Opin. Plant Biol., 5: 237-243.

Raaman, N. 2006. Phytochemical techniques. In: New Indian Publishing-Botanical Chemistry, New Delhi Pp.19-24.

Rao, A.S., Reddy, S.G., Babu, P.P., Reddy, A.R. 2010. The antioxidant and antiproliferative activities of methanolic extracts from Njavara rice bran. BMC Complement Altern. Med., 10: 4 .
Rao, B., Narasinga. 2003. "Bioactive phytochemicals in Indian foods and their potential in health promotion and disease prevention." Asia Pacific J. Clin. Nutri., 12(1): 9-22.

Singh, R., S. Singh. 2007. Food Chem. Toxicol., 45: 1216-1223.

Sofowora, A. 1993. Medicinal plants and traditional medicine in Africa. Ibadan: Spectrum books Ltd, p. 55-7.

Tarali Chowdhury. 2014. "Virtual screening of compounds derived from Garciniapedunculata as an inhibitor of gamma hemolysin component $\mathrm{A}$ of Staphylococcus aureus." Bangladesh J. Pharmacol., 9(1): 67-71.

\section{How to cite this article:}

Jayasudha, M., R.K. Sumathi and Dinesh, M.D. 2016. Comparison of Phytochemical and invitro Antimicrobial Evaluation of Methanolic Extracts of Garcinia gummi-gutta. Int.J.Curr.Microbiol.App.Sci. 5(12): 72-78. doi: http://dx.doi.org/10.20546/ijcmas.2016.512.008 